\title{
Actions: ACRL Board of Directors, February 1995
}

\section{Highlights of the ACRL Board of Directors' Midwinter meetings}

$\mathbf{T}$ he Board of Directors of the Association of College and Research Libraries met twice during the Midwinter Meeting in Philadelphia on February 5 and February 7, 1995. Highlights of their meetings are as follows:

Endorsed the ACRL Resolution supporting the ALA Goal 2000 Initiatives and the proposed dues increase, and pledged $\$ 50,000$ to the Fund for America's Libraries. Ed. note: ACRL's publication Choice also pledged $\$ 50,000$ to the project.

Approved RBMS request for 1996 preconference, "Taking Stock: Setting the Agenda for Special Collections in the 21st Century," in Ithaca, New York, July 2-5, 1996.

Endorsed the ALA Subcommittee on Copyright's Resolution on Intellectual Property Rights and its Resolution on the Copyright Reform Act.

Approved policy to waive registration fees for up to three Preconference Planning or Local Arrangements chairs for each preconference.

Accepted a report from the BIS Emerging Technologies Committee and asked the section to continue its work with the Coalition for Networked Information to develop responses to the recommendations regarding broadening use of the Internet as a mode of instruction.

Approved a proposal outline for developing a grant proposal to seek funding to support the ACRL/AAHE-EASI (American Association of Higher Education-Equal Access to Software Information) project to develop an online workshop to inform librarians and administrators of resources and research on improving services to the physically challenged.

Approved a joint proposal with the University of Illinois at Chicago to develop a Building Community Information Organizations Initiative that will place academic librarians in leadership roles to direct citizen access to public information.

Approved two possible statements that could be themes for ACRL's 8th National Conference in Nashville, April 11-14, 1997, pending copyright clearance.

Approved cosponsorship for LITA's "Geographic Information Systems: An Introduction” preconference, June 23, 1995.

Approved a request for the Bibliographic Instruction Section to change its name to the Instruction Section.

Endorsed the resolution from the ALA International Relations Committee to support Library Fellows and Fulbright programs.

Approved a Copyright Committee request for a 1996 preconference in New York City on electronic reserves in libraries.

Approved five-year review reports and the continuance of the Extended Campus Library Services Section (ECLSS) and the Law and Political Science Section (LPSS)

Approved the revised "Standards for College Libraries." (See page 245 in this issue.)

At the request of LPSS approved the establishment of the annual Marta Lange/CQ Award (Actions cont. on page 257) 


\section{- ACS Publications Landmarks In Science}

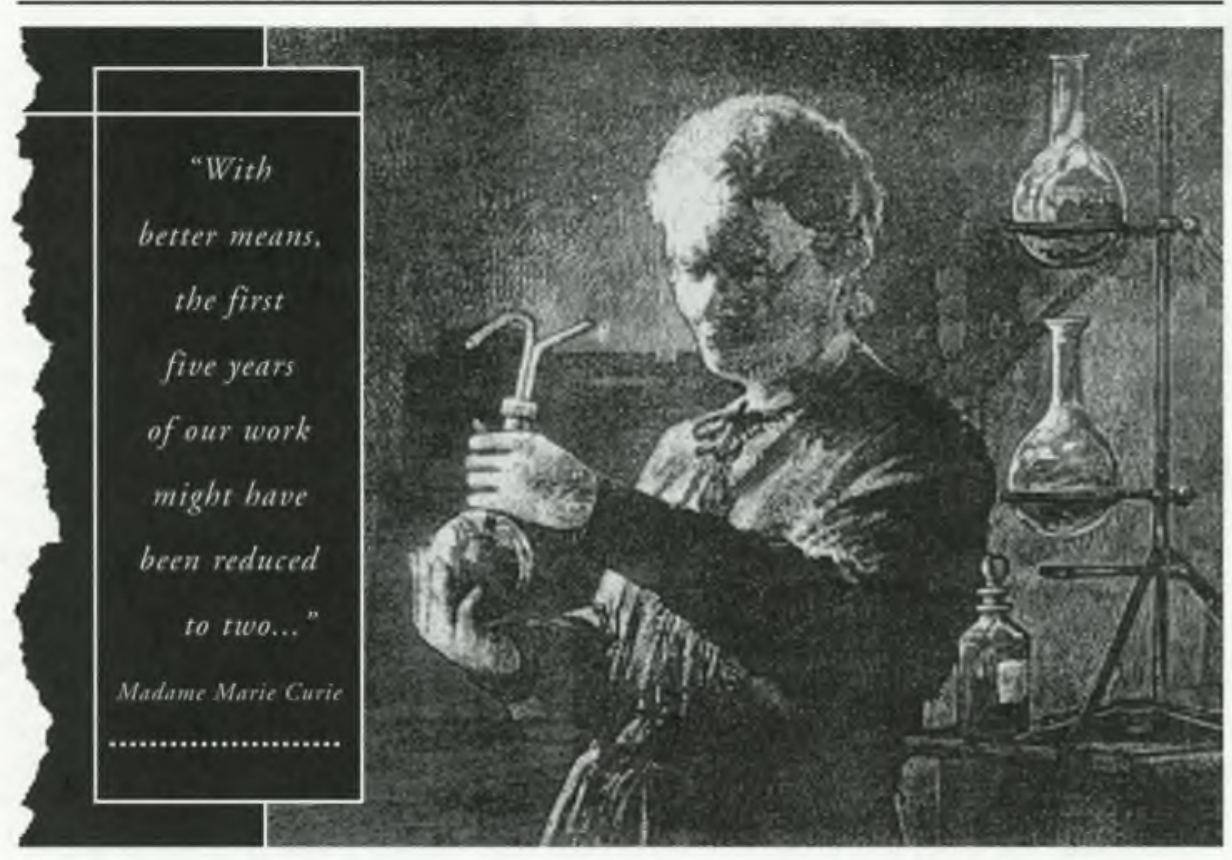

\section{Madame Curie On The Cost Of Science.}

She discovered radium. She coined the word "radioactive" and was the first to suspect it emanared from "atomic energy." Twice winner of the Nobel Prize, her discoveries led to the development of radiation therapy for the treatment of cancer. Yet in spite of her wide acclaim, Madame Curie often had to beg from the wealthy to fund her research. She understood the painful cost of science.

So do we. Since 1876, when the American Chemical Sociery first began to publish scientific journals, we have consistently offered them at affordable subscription rates. ACS journals cost, on average, about $50 \% *$ of the price charged for competitive publications in our discipline. And we are committed to continuing this tradition, without compromising the quality of science we publish.
Today, the chemical sciences are advancing at a staggering rate. We've increased our page budgets and our publication frequencies to keep pace with the increased flow of critical research. And we've invested in new technology that increases the speed at which we can publish without reducing the stringent standards of our peer review process.

We will always look for new ways to continue our pioneering role as publishers of quality science, because we re working hard to provide tomorrow's landmark scientists with the means to afford today's research.

\section{ACS IIIPUBLICATIONS Errential Resoumes for the Chemical Sciences} 1155 Sixternth St. NW, Washington, D.C. 20036 USA

${ }^{*}$ According to a report in the April 15, 1994 issue of Library Journal, the chemical sciences had an average price per journal of $\$ 1,106$. 
creditation Criteria and the Standards for College Libraries: The Informal Role of Quantitative Input Measures for Libraries in Accreditation," Journal of Academic Librarianship 20 (November 1994): 273-84.

Hardesty, Larry, and Stella Bentley. The Use and Effectiveness of the 1975 Standards for College Libraries: A Survey of College Library Directors (1981).. Unpublished paper.

Kaser, David. "Standards for College Libraries." Library Trends 31:1 (Summer 1982): 7-19.

Kroll, Susan, ed. Academic Status: Statements and Resources, 2 nded. Chicago: ACRL/ALA, 1994.

Leach, Ronald G., and Judith E. Tribble. "Electronic Document Delivery: New Options for Libraries." Joumal of Academic Librarianship 18 (January 1993): 359-64.

Matier, Michael, and C. Clinton Sidle. "What Size Libraries for 2010?" Planning for Higher Education 21 (Summer 1993): 9-15.

Morgan, Robert L. Classification of Instructional Programs, 1990 edition. Washington, D.C.: National Center for Education Statistics, 1991.
Sacks, Patricia Ann, and Sara Lou Whildin. Preparing for Accreditation; a Handbook for Academic Librarians. Chicago: ALA, 1993.

Stueart, Robert D., and Barbara B. Moran.

"Missions, Goals and Objectives." In Library and Information Center Management, 4th ed. Englewood, Colo.: Libraries Unlimited, 1993, pp. 43-45.

U.S. Code. 1-810. "Act for the General Revision of the Copyright Law." October 9, 1976. Public Law 94-553,90 Stat. 2541.

Walch, David B. "The 1986 College Library Standards: Application and Utilization." College E Research Libraries 54 (May 1993): 217-26.

(Ed. note: Committee members ubo worked on the 1995 edition are: Diane C. Parker, chair, Western Wasbington University; Barbara Bryan, Fairfield University; Paul Coleman, Adrian College; Jan Fennell. Geongia College, Milledgeville; Dalia Hagan, St.Martins College; Ada Jarred, Nortbwestern State University of Louisiana; Eric Kidwell, Huntingdon College; Grady Morein, University of West Florida; and Norma Yueb, Ramapo College of New Jersey.)
(Actions cont. from page 240)

for Law Librarians with a cash prize of $\$ 1,000$ and a citation donated by Congressional Quarterly.

\section{Approved a recommendation to redefine} the Professional Liaison Committee and designated the Executive Director to chair the committee.

Approved ACRL Priorities for 1995-1996. The priorities are:

1) Expand information, programs, and delivery mechanisms that will enhance the leadership abilities of academic librarians.

2) Provide leadership within the higher education community on library and information issues.

3) Build strategic alliances among ACRL units, ALA divisions, and the broader higher education community to advance ACRL priorities.

Approved an amendment to the Initiative Fund Criteria to include projects supporting ALA Goal 2000.

Approved the addition of a Board/Leadership meeting to its scheduled official meetings held at Annual Conferences and Midwinter Meetings.

Approved the discontinuance of the regional appointment basis for the Membership Committee and established a task force to develop a new strategy.

Approved the ACRL/CNI (Coalition for Networked Information) preconference, "The Networked Professional," for 1996 in New York.

Established a policy for reporting to the Board on funded initiative projects that requires project directors to submit a report of activities at the time the request is made for final payment.

Approved 0.95 FTE staff increase for the 1996 budget year to support ACRL's production of College $\&$ Research Libraries and to handle conference and preconference activities like registration and exhibits management.

Approved the 1996 preliminary budget with revenue of $\$ 974,967$ and expenses of $\$ 1,211,306$. 